\title{
Record of abundance, spatial distribution and gregarious behavior of invasive lionfish Pterois spp. (Scorpaeniformes: Scorpaenidae) in coral reefs of Banco Chinchorro Biosphere Reserve, southeastern Mexico
}

\author{
Miguel Mateo Sabido-Itzá ${ }^{1}$ \& María del Carmen García-Rivas ${ }^{2}$ \\ ${ }^{1}$ Instituto Tecnológico de Chetumal, Maestría en Manejo de Zona Costera, Quintana Roo, México \\ ${ }^{2}$ Comisión Nacional de Áreas Naturales Protegidas, Parque Nacional Isla Contoy y Parque Nacional \\ Arrecifes de Puerto Morelos, Puerto Morelos, Quintana Roo, México \\ Corresponding author: Miguel Sabido-Itzá (mateosabido@gmail.com)
}

\begin{abstract}
The lionfish (Pterois volitans, P. miles) is the first known species of marine fish to invade the Caribbean and Gulf of Mexico, and it is threatening the biodiversity of the region's coral reefs. Its success as an invasive species is due to its high predation and fertility, fast growth and lack of predators. Its first recorded appearance in Mexico was in 2009. Twenty-two sites were monitored around the reef of Banco Chinchorro Biosphere Reserve (BCBR), to estimate their abundance, during 2013. Densities from 0 to 333 ind ha ${ }^{-1}$ (97.6 \pm 140.2 ind ha $\left.{ }^{-1}\right)$ and biomasses from 0 to $58.7 \mathrm{~kg} \mathrm{ha}^{-1}\left(18.2 \pm 29.9 \mathrm{~kg} \mathrm{ha}^{-1}\right)$ were recorded, the highest so far in the Mexican Caribbean. In addition, two lionfish distribution zones were detected: leeward reef (LR) and windward reef (WR). LR was 4.6 and 3.9 times higher in density and biomass than WR, respectively. The sizes found in the monitoring ranged from 5 to $40 \mathrm{~cm}$ of total length. Finally, a gregarious behavior was observed in $47.5 \%$ of the recorded fish. Our results suggest that to prevent the development of large reservoirs of lionfishes in the BCBR, management and control actions in areas of high lionfish abundance should be prioritized.
\end{abstract}

Keywords: Pterois volitans; Pterois miles; lionfish; invasive species; Banco Chinchorro; leeward reef; gregarious behavior; Mexican Caribbean

The invasion of lionfishes (Pterois volitans, P. miles) is considered one of the greatest threats to biodiversity in the Atlantic Ocean (Hixon et al., 2016). In three decades, lionfishes invaded and settled in the eastern coasts of the United States, the Caribbean Sea, the Gulf of Mexico and the southeastern coast of Brazil (Côté \& Smith, 2018), reaching higher densities than in its native area (Darling et al., 2011; Kubicki et al., 2012). Its presence in reefs has caused ecological impacts triggering a decrease in the density and biomass of native fishes (Albins, 2015), and competing for space and food with species of a similar trophic level (Albins, 2013). The direct effects of the lionfish could be combined with other stressors such as overfishing and pollution in Caribbean reefs (Albins \& Hixon, 2013), resulting in a biodiversity crisis.

In Banco Chinchorro, Mexico, the first lionfish (14 $\mathrm{cm}$ total length) was captured by a fisherman nearby
Cayo Centro area, at 3 m water depth on 9 July 2009. However, it is very likely that the invasion had begun years before the first sighting (Sabido-Itzá et al., 2016b). The impacts of the rapid population establishment on Mexican coasts is just beginning to be understood (García-Rivas et al., 2018).

The objectives of this study are to describe the abundance (density and biomass), spatial distribution, size structure, and gregarious behavior of the lionfishes in Banco Chinchorro Biosphere Reserve (BCBR). "Lionfish" and Pterois spp. refer to both species, due to the recent record of $P$. miles in BCBR (GuzmánMéndez et al., 2017). This Marine Protected Area is considered a priority in the Mesoamerican Reef System region, so the results presented here are important to determine the course of monitoring and control efforts.

The Chinchorro reef system is in the southeastern of the Yucatan Peninsula, Mexico $\left(18^{\circ} 47^{\prime}-18^{\circ} 23^{\prime} \mathrm{N}\right.$,

Corresponding editor: Guido Plaza 


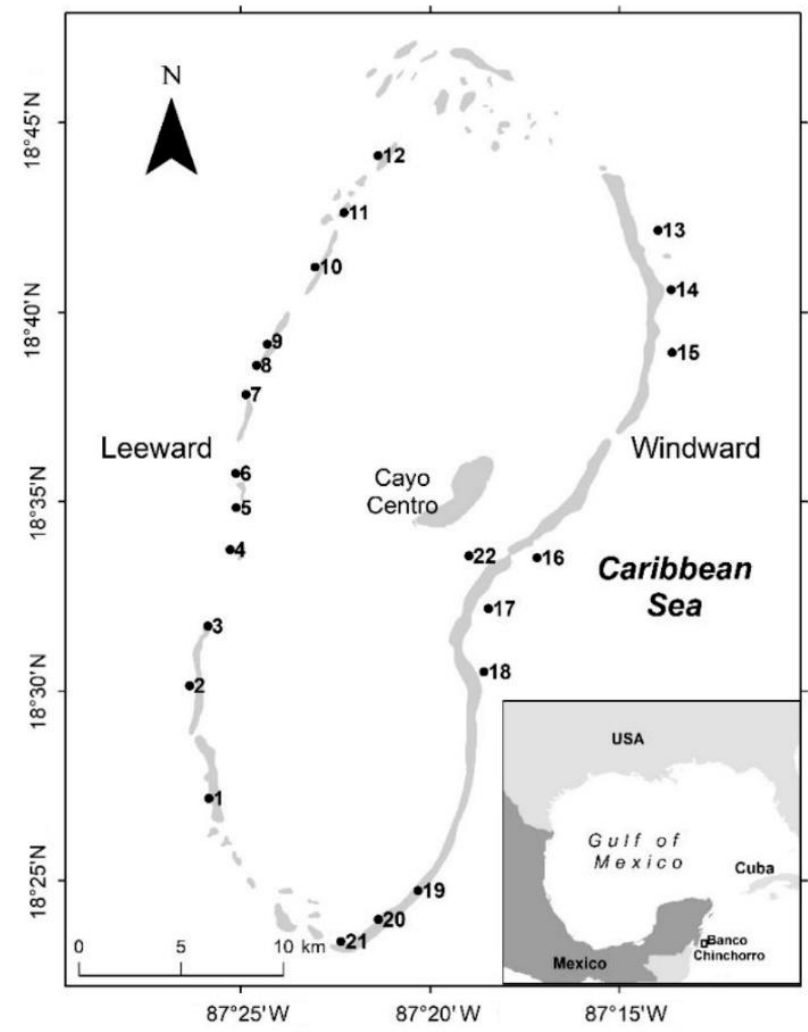

Figure 1. Monitoring sites of lionfish Pterois spp. in Banco Chinchorro Biosphere Reserve (BCBR), Mexico.

$\left.87^{\circ} 14^{\prime}-87^{\circ} 27^{\prime} \mathrm{W}\right)$ (Carricart-Ganivet \& Beltrán-Torres, 1998), $30.8 \mathrm{~km}$ away from the mainland and separated from the coast by a 1,000 $\mathrm{m}$ deep channel (Fig. 1).

In order to estimate the abundance and distribution of the lionfish in the reefs of BCBR, four sites were monitored (4, 5, 8 and 10) in 2012, and 22 sites in 2013 from March to May between 09:00 $\mathrm{h}$ and 12:00 $\mathrm{h}$. Depending on the depth and sea conditions, between four and six visual censuses of $30 \mathrm{~m}$ length and $4 \mathrm{~m}$ width were performed, deployed parallel to the main reef formation at each site. To avoid bias in the detection of lionfish, two people trained in monitoring performed censuses. Each diver did a thorough search in cavities, overhangs, cracks and any potential habitat, recording the total number of lionfishes in each transect, visually estimating the size of all fishes to the nearest centimeter and its gregarious behavior. This methodology was adapted from that proposed by Green et al. (2013).

The recorded lengths of the lionfishes were converted to weight using the length-weight relationship parameters ( $a=0.0042, b=3.258$ ), obtained from SabidoItzá et al. (2016a). The biomass was estimated as the sum of fish weights recorded in a transect. A $t$-test was used to determine differences in density and biomass between years and a Simple Variance Analysis
(ANOVA) was used to determine statistical differences in density and biomass between sites and distribution zones in 2013, followed by a post-hoc LSD-Fisher test.

The data were transformed to $\log (\mathrm{x}+1)$, due to a large number of zeros found in transects. The normality and homogeneity of variance were tested by the Shapiro-Wilks and Levene's tests, respectively. The lengths and weights were evaluated by zone using the $t$-test.

Lionfish groups were classified into four categories: lone individual, group of two, group of three and group of $\geq 4$ fish. The number of lionfishes showing some grouping ( $\geq 2$ organisms) among the total recorded fish, resulted in the relative gregarious behavior. Finally, the mean cluster size (\# fish) was obtained among the total groupings observed.

Four sites were monitored on the leeward side to compare densities and biomass between 2012 and 2013, and we found that in 2013 the densities were 1.9 times greater than in $2012(75.36 \pm 106.70$ vs $147.73 \pm$ $166.53)$ and biomass was similar $(18.86 \pm 27.93$ vs $20.42 \pm 27.02)$. However, no significant difference was found between years $(t=-0.72, P=0.47$ and $t=0.76$, $P=0.45)$.

At the 22 sites monitored in 2013, the average density and biomass (mean \pm SD) found in BCBR was $97.58 \pm 140.25$ ind $\mathrm{ha}^{-1}$ and $18.20 \pm 29.88 \mathrm{~kg} \mathrm{ha}^{-1}$ respectively (Table 1$)$. At the sites, significant differences were found between densities (ANOVA: $\mathrm{F}_{21,95}=$ 2.6, $P<0.001$ ) and biomass (ANOVA: $\mathrm{F}_{21,92}=2.6, P<$ $0.001)$.

There was a marked difference in density and biomass of Pterois spp. at sites located in the leeward reefs (LR) with respect to those located in the windward reef (WR), (ANOVA: $\mathrm{F}_{1,115}=30.01, P<0.000$ and ANOVA: $\mathrm{F}_{1,112}=23.29, P<0.000$ for density and biomass respectively). LR mean density was 4.6 times higher than WR $\left(154.57 \pm 163.8\right.$ vs $33.33 \pm 63.3$ ind ha $\left.^{-1}\right)$. The mean biomass was 3.9 times higher in LR than WR $\left(28.42 \pm 35.0\right.$ vs $\left.7.25 \pm 17.8 \mathrm{~kg} \mathrm{ha}^{-1}\right)$ (Figs. 2a-2b).

Total length ranged from 5 to $40 \mathrm{~cm}(23.4 \pm 9 \mathrm{~cm})$, while weight ranged from 0.8 to $696.4 \mathrm{~g}(188.2 \pm 179.3$ g). Because no difference was found between LR and WR sizes $(t=0.25, P=0.80)$, total lengths were all grouped into a histogram (Fig. 3). From the total number of observations, $47.5 \%$ of the lionfishes presented some sort of aggregation. Finally, the number of groups of lionfishes was higher in LR (24) than WR (2) (Table 2).

Data collected in this study confirm the settlement and wide distribution of Pterois spp. on the reefs of the BCBR, Mexico. The lionfish densities and biomass are 
Table 1. Lionfish (Pterois spp.) density and biomass in monitored sites in 2013 in Banco Chinchorro Biosphere Reserve (BCBR), Mexico. SD: standard deviation.

\begin{tabular}{|c|c|c|c|}
\hline \multirow{2}{*}{ Zone } & \multirow{2}{*}{ Site } & \multicolumn{2}{|c|}{2013} \\
\hline & & Density \pm SD $\left(\right.$ ind ha $\left.{ }^{-1}\right)$ & Biomass \pm SD $\left(\mathrm{kg} \mathrm{ha}^{-1}\right)$ \\
\hline \multirow{12}{*}{ Leeward reef } & 1 & $125 \pm 87.40$ & $32.15 \pm 23.11$ \\
\hline & 2 & $20.83 \pm 41.67$ & $4.54 \pm 9.08$ \\
\hline & 3 & $152.78 \pm 97.42$ & $33.46 \pm 31.94$ \\
\hline & 4 & $83.33 \pm 58.92$ & $22.93 \pm 14.28$ \\
\hline & 5 & $222.22 \pm 291.86$ & $28.15 \pm 42.46$ \\
\hline & 6 & $145.83 \pm 125$ & $50.82 \pm 57.46$ \\
\hline & 7 & $333.33 \pm 68.04$ & $40.85 \pm 32.81$ \\
\hline & 8 & $152.78 \pm 97.42$ & $4.68 \pm 4.04$ \\
\hline & 9 & $291.67 \pm 296.98$ & $51.77 \pm 53.80$ \\
\hline & 10 & $116.67 \pm 95.01$ & $27.54 \pm 28.65$ \\
\hline & 11 & $166.67 \pm 117.85$ & $58.74 \pm 41.20$ \\
\hline & 12 & $41.67 \pm 69.72$ & $0.61 \pm 1.20$ \\
\hline \multirow[t]{11}{*}{ Windward Reef } & 13 & $20.83 \pm 41.67$ & $9.39 \pm 18.78$ \\
\hline & 14 & $55.56 \pm 68.04$ & $6.99 \pm 13.96$ \\
\hline & 15 & $13.89 \pm 34.02$ & $2.09 \pm 5.12$ \\
\hline & 16 & 0 & 0 \\
\hline & 17 & $41.67 \pm 45.64$ & $0.92 \pm 1.72$ \\
\hline & 18 & $41.67 \pm 45.64$ & $11.36 \pm 12.45$ \\
\hline & 19 & $33.33 \pm 74.54$ & $12.78 \pm 28.57$ \\
\hline & 20 & $100 \pm 149.07$ & $29.13 \pm 41.07$ \\
\hline & 21 & $16.67 \pm 37.27$ & $4.54 \pm 10.16$ \\
\hline & 22 & $13.89 \pm 34.02$ & $0.11 \pm 0.26$ \\
\hline & Total & $97.58 \pm 140.25$ & $18.20 \pm 29.88$ \\
\hline
\end{tabular}
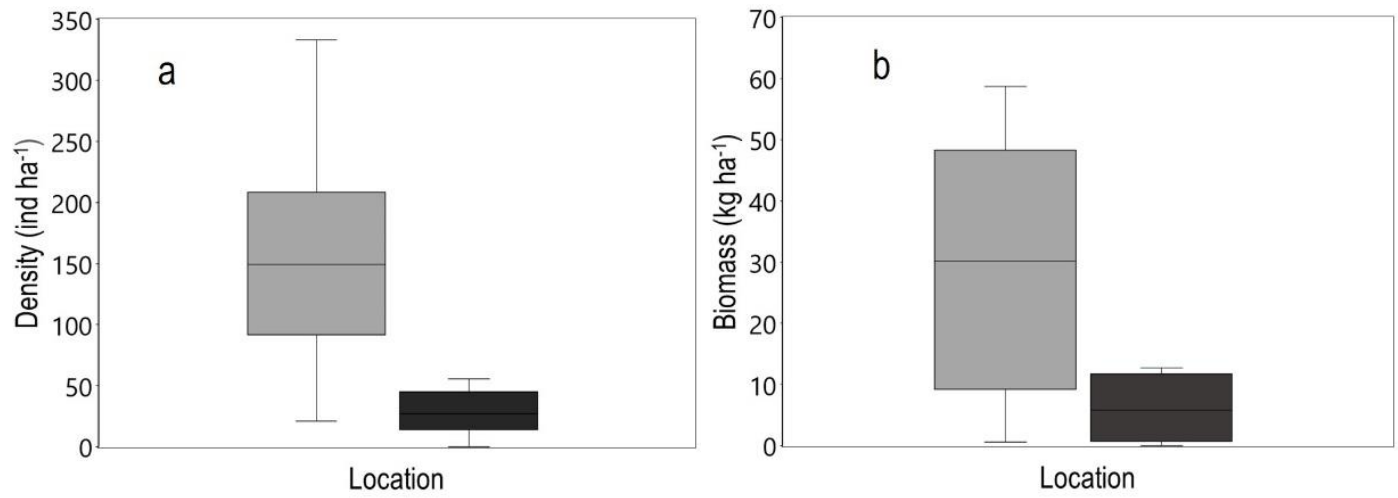

Figure 2. Comparison of the abundance of lionfish Pterois spp. between the leeward reef (light gray) and the windward reef (dark gray) in the Banco Chinchorro Biosphere Reserve (BCBR), Mexico. a) Density, b) Biomass.

higher than in their native environment, confirming previous results of comparisons for other invaded areas (Darling et al., 2011; Kulbicki et al., 2012).

Densities reported here can be considered as intermediate, within the invaded range, because sites with densities below 50 ind ha $^{-1}$ and sites above 300 ind $\mathrm{ha}^{-1}$ have been recorded (Table 3). Sites with high densities (>300 ind $\left.\mathrm{ha}^{-1}\right)$, may present significant negative changes in the native reef-fish community (Albins, 2015).

Biomass in BCBR was very similar to that found in New Providence, in the Bahamas, with $19.2 \pm 29.3 \mathrm{~kg}$ $\mathrm{ha}^{-1}$. Nevertheless, it was 6 to 12 times higher than that found in San Salvador Island and Kenya with 2.7 and $1.5 \mathrm{~kg} \mathrm{ha}^{-1}$, respectively (Darling et al., 2011; Anton et al., 2014). The wide variety of density and biomass 


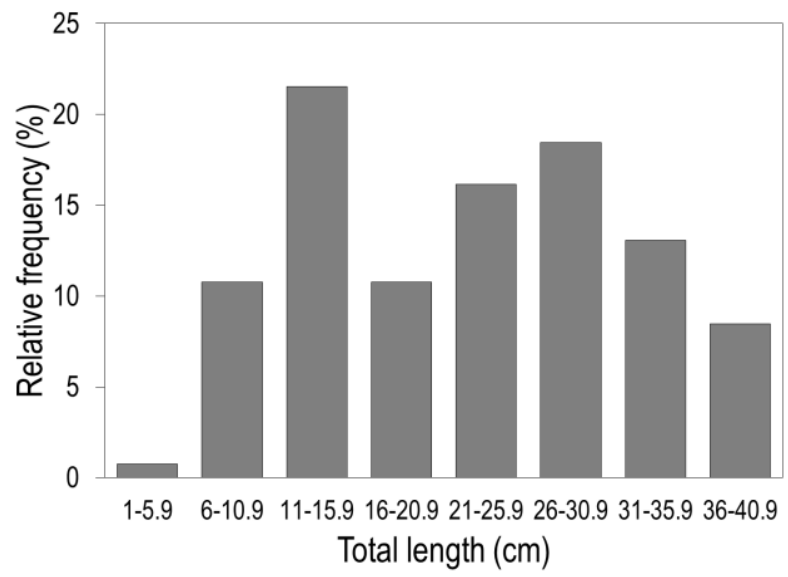

Figure 3. Distribution of the relative frequencies of the lengths of lionfish Pterois spp. in the Banco Chinchorro Biosphere Reserve, Mexico. records reported here and in the Atlantic Ocean may be related to factors characteristic of the biogeographic region (Hackerott et al., 2013; Cure et al., 2014), the year of the first report and subsequent monitoring (Cobián-Rojas et al., 2016), habitat (Lesser \& Slattery, 2011; Anton et al., 2014; Bejarano et al., 2015), or the methodology used in sampling (Green et al., 2013; Tilley et al., 2016).

The location of sites in BCBR, relative to wave exposure, had a great influence on the values of the density and biomass of Pterois spp. Chollett \& Mumby (2012) mentioned that the winds in the region are predominantly northeastern, dominating the patterns of wave exposure, i.e., causing fewer waves on the leeward side than in the windward direction. Lack of wave exposure in LR favors the presence of lionfish while the higher waves inhibit their hunting functions (Anton et al., 2014; García-Rivas et al., 2018). Also,

Table 2. Gregarious behavior of lionfish Pterois spp. in Banco Chinchorro Biosphere Reserve, Mexico. Data are presented as the total number of registered fish $\left(\mathrm{N}^{\circ}\right.$ fish), the number of solitary fishes, the total number of registered groups, group number 2, 3 and from 4 to 7 fish and the average \pm SD group size. n: number of fishes, \%: percentage of each group.

\begin{tabular}{cccccccc}
\hline & $\begin{array}{c}\mathrm{N}^{\circ} \\
\text { fish }\end{array}$ & Solitary & $\begin{array}{c}\mathrm{N}^{\circ} \text { groups } \\
\text { total }\end{array}$ & $\begin{array}{c}\text { Groups of } \\
\text { two fishes }\end{array}$ & $\begin{array}{c}\text { Groups of } \\
\text { three fishes }\end{array}$ & $\begin{array}{c}\text { Groups of four } \\
\text { to seven fishes }\end{array}$ & $\begin{array}{c}\text { Mean group } \\
\text { size }\end{array}$ \\
\hline $\mathrm{n}$ & 137 & 72 & 26 & 18 & 6 & 2 & $2.5 \pm 1.1$ \\
$\%$ & 100 & 52.5 & 47.5 & 26.3 & 13.1 & 8.1 & \\
\hline
\end{tabular}

Table 3. Densities of lionfish Pterois spp. reported in native and invaded sites. SD: standard deviation.

\begin{tabular}{llccl}
\hline Region & Locality & Density & Media \pm SD $\left(\right.$ ind ha $\left.^{-1}\right)$ & Source \\
\hline Native & Philippines & Low & $21.94 \pm 6.5$ & Cure et al. $(2014)$ \\
Native & Guam & Low & $3.53 \pm 0.9$ & Cure et al. $(2014)$ \\
Native & Mombasa, Kenya & Low & $25.1 \pm 45.7$ & Darling et al. $(2011)$ \\
Native & Red Sea & Low & $24.1 \pm 44.9$ & McTee \& Grubich $(2014)$ \\
Native & Pacific Ocean & Low & 0.17 & Kulbicki et al. $(2012)$ \\
Native & Indian Ocean & Low & 3.6 & Kulbicki et al. $(2012)$ \\
Invaded & Island of San Salvador, Bahamas & Low & $13 \pm 18$ & Anton et al. $(2014)$ \\
Invaded & Venezuelan coast & Low & $25.83 \pm 66.51$ & Agudo \& Klein-Salas (2014) \\
Invaded & South Caicos, Turks \& Caicos Islands & Low & 16.79 & Tilley et al. $(2015)$ \\
Invaded & Bacalar Chico, Belize & Low & $27.1 \pm 8.8$ & Chapman et al. $(2016)$ \\
Invaded & New Providence, Bahamas & Medium & $101.7 \pm 103$ & Darling et al. $(2011)$ \\
Invaded & Curaçao & Medium & 127 & de León et al. $(2013)$ \\
Invaded & Bonaire & Medium & 66 & de León et al. $(2013)$ \\
Invaded & Little Cayman, Cayman Islands & Medium & 162 & Bejarano et al. $(2015)$ \\
Invaded & Lee Stocking Island, Bahamas & High & $530 y 640$ & Lesser \& Slattery $(2011)$ \\
Invaded & Cape Eleuthera, Bahamas & High & $300 \pm 600$ & Green et al. $(2013)$ \\
Invaded & Guanahacabibes, Cuba & High & 310 & Cobián-Rojas et al. (2016) \\
Invaded & San Andrés, Colombia & High & $379 \pm 220$ & González-Corredor et al. (2016) \\
Invaded & Banco Chinchorro, Mexico & Medium & $97.6 \pm 140.2$ & This study \\
\hline
\end{tabular}


LR is likely to serve as a feeding ground for lionfishes, due to the high abundance of reef fish recruits (Villegas-Sánchez et al., 2015). Ocean currents can also play an important factor. On the western flank on the BCBR, the currents usually move south (anticyclonically) slowly, allowing for the retention and settlement of larvae (Carrillo et al., 2015).

Sizes and weights found in the BCBR are like that of various regions in the Atlantic Ocean (Sabido-Itzá et al., 2016b; Chapman et al., 2016; Cobián-Rojas et al., 2016). Rapid growth rates (Côté \& Smith, 2018) and high prey consumption have helped to achieve greater lengths than those found in its natural range (Darling et al., 2011). In our study, about $65 \%$ of the organisms were considered sexually mature, i.e., the population is dominated by adults (Gardner et al., 2015).

Finally, it has been reported that in their natural habitat (Cure et al., 2014; McTee \& Grubich, 2014) and in the Atlantic Ocean (Agudo \& Klein-Salas, 2014: García-Rivas et al., 2018), the herding behavior of the lionfish is common. In Venezuela, gregarious behavior was reported for $44 \%$ of the individuals, whereas in the Philippines and Guam in the Pacific Ocean was 54 and $26 \%$ respectively (Agudo \& Klein-Salas, 2014; Cure et al.,2014). The average number of lionfishes found in groups in BCBR was less (2.5 ind) than that found in their native communities (4.9 and 3.8 ind) (Cure et al., 2014). Regarding survey areas, LR presents a major proportion of groups than WR. Ecologically, these aggregations serve to increase the success of hunting and reproduction, which can be more significant in LR due to the availability of potential preys and abundance of lionfish for possible mating (García-Rivas et al., 2018).

Since the earliest records of lionfish specimens in Mexico, authorities have implemented actions such as fishing tournaments (Malpica-Cruz et al., 2016) and promoted its use for consumption (Carrillo-Flota \& Aguilar-Perera, 2017) to try to reduce its abundance and the consequent impact on local ecosystems. In Banco Chinchorro, management is based on capture during fishing tournaments and by daily catch brigades for approximately five months with local anglers and tourist service providers. However, our results show that at least as of 2013, the abundance of lionfish has not diminished. Therefore, better planning is needed. Our recommendation is to promote lionfish extraction from leeward reefs in order to benefit and aid in the conservation of the native species that inhabit this area. This work serves to understand the distribution of the lionfish in the BCBR. Now, studies that focus on corroborating the environmental factors that determine the distribution of the lionfish, its impacts in the native reef-fish community and the efficacy of ongoing removals in the Mexican coasts are required.

\section{ACKNOWLEDGMENTS}

We thanks the GEF/Small Grants Programme for the financial support provided by the project MEX/ SGP/OP5/FSP/STAR/BD/13/51. To the National Commission of Natural Protected Areas (CONANP), to the Banco Chinchorro Biosphere Reserve, to its assigned personnel, especially José DomínguezCalderón, Yareni Perera-Romero and Angel MorenoBeltrán. Likewise, this work would not have been possible without the support of the fishermen of the three fishing cooperatives, in particular, Emiliano Martínez, Miguel Jarillo, Manuel Frías, Erick Xicum, Jaime Medina and Didier García. We thank Dr. Nuno Simoes for his accurate observations, Dra. Anastazia Banaszak for the English translation and Irving Chávez for helping in editing figures.

\section{REFERENCES}

Agudo, E. \& Klein-Salas, E. 2014. Lionfish abundance, size structure, and spatial distribution along the Venezuelan coast (Pterois volitans, Pteroinae: Scorpaenidae). Revista de Biología Tropical, 62(3): 151-158.

Albins, M.A. 2013. Effects of invasive Pacific lionfish Pterois volitans network versus a native predator on coral-reef fish Bahamian communities. Biological Invasions, 15(1): 29-43.

Albins, M.A. 2015. Pacific invasive lionfish Pterois volitans reduces abundance and species richness of native Bahamian coral-reef fishes. Marine Ecology Progress Series, 522: 231-243.

Albins, M.A. \& Hixon, M.A. 2013. Worst case scenario: potential long-term effects of invasive predatory lionfish (Pterois volitans) on Atlantic and Caribbean coral reef communities. Environmental Biology of Fishes, 96(10): 1151-1157.

Anton, A., Simpson, M.S. \& Vu, I. 2014. Environmental and biotic correlates to lionfish invasion success in Bahamian coral reefs. Plos One, 9(9): e106229.

Bejarano, S., Lohr, K., Hamilton, S. \& Manfrino, C. 2015. Relationships of invasive lionfish with topographic complexity, groupers, and native prey fishes in Little Cayman. Marine Biology, 162(2): 253-266.

Carricart-Ganivet, J.P. \& Beltrán-Torres, A.U. 1998. Chinchorro Bank: a threatened Mexican Caribbean atoll. Coral Reefs, 17(1): 36.

Carrillo, L., Johns, E.M., Smith, R.H., Lamkin, J.T. \& Largier, J.L. 2015. Pathways and hydrography in the 
Mesoamerican Barrier Reef System Part 1: Circulation. Continental Shelf Research, 109: 64-176.

Carrillo-Flota, E.C. \& Aguilar-Perera, A. 2017. Stakeholder perceptions of network lionfish (Pterois volitans) as a threat to the ecosystem, and its potential for human consumption in Quintana Roo, Mexico. Ocean \& Coastal Management, 136: 113-119.

Chapman, J.K., Anderson, L.G., Gough, C.L.A. \& Harris, A.R. 2016. Working up an appetite for lionfish: a market-based approach to manage the invasion of Pterois volitans in Belize. Marine Policy, 73: 256-262.

Chollett, I. \& Mumby, P.J. 2012. Predicting the distribution of Montastraea reefs using wave exposure. Coral Reefs, 31(2): 493-503.

Cobián-Rojas, D., Chevalier-Monteagudo, P.P., SchmitterSoto, J., Corrada-Wong, R., Salvat-Torres, H., Cabrera-Sansón, E., García-Rodríguez, A.G., Fernández-Osorio, A., Espinosa-Pantoja, L., CabreraGuerra, D., Pantoja-Echevaria, L.M., CaballeroAragón, H. \& Perera-Valderrama, S. 2016. Density, size, biomass, and diet of lionfish in Guanahacabibes National Park, western Cuba. Aquatic Biolology, 24(3): 219-226.

Côté, I.M. \& Smith, N.S. 2018. The lionfish Pterois sp. invasion: has the worst-case scenario come to pass? Journal of Fish Biology, 92: 660-689.

Cure, K., McLean, J.L. \& Hixon, M.A. 2014. Habitat plasticity in native Pacific lionfish Pterois volitans network facilitates successful invasion of the Atlantic. Marine Ecology Progress Series, 506: 243-253.

Darling, E.S., Green, S.J., O'Leary, J.K. \& Côté, I.M. 2011. Indo-Pacific lionfish are larger and more abundant on invaded reefs: a comparison of Kenyan and Bahamian lionfish populations. Biological Invasions, 13(9): 2045-2051.

García-Rivas, M.C., Machkour-M'Rabet, S., PérezLachaud, G., Schmitter-Soto, J.J., Céréghino, R., Doneys, C., St-Jean, N. \& Hénaut, Y. 2018. Agedependent strategies related to lionfish activities in the Mexican Caribbean. Environmental Biology of Fishes, 101(4): 563-578.

Gardner, P.G., Frazer, T.K., Jacoby, C.A. \& Yanong, R.P.E. 2015. Reproductive biology of invasive lionfish (Pterois spp.). Frontiers in Marine Science, 2: 7. https://doi.org/10.3389/fmars.2015. 00007.

González-Corredor, J.D., Acero, A. \& García-Urueña, R. 2016. Densidad y estructura de tallas del pez león Pterois volitans (Scorpaenidae) en el Caribe occidental insular colombiano. Boletin de Investigaciones Marinas Costeras, 45(2): 317-333.

Green, S.J., Tamburello, N., Miller, S.E., Akins, J.L. \& Côté, I.M. 2013. Habitat complexity and fish size affect the detection of Indo-Pacific lionfish on invaded coral reefs. Coral Reefs, 32(2): 413-421.
Guzmán-Méndez, I.A., Rivera-Madrid, R., Díaz-Jaimes, P., García-Rivas, M.C., Aguilar-Espinosa, M. \& Arias-González, J.E. 2017. First confirmed record of the genetically devil firefish Pterois miles invasive (Bennett, 1828) in the Mexican Caribbean. BioInvasions Records, 6(2): 99-103.

Hackerott, S., Valdivia, A., Green, S.J., Côté, I.M., Cox, C.E., Akins, J.L., Layman, C.A., Precht, W.F. \& Bruno, J.F. 2013. Native predators do not influence invasion success of Pacific lionfish on Caribbean reefs. Plos One, 8(7): e68259.

Hixon, M.A., Green, S.J., Albins, M.A., Akins, J.L. \& Morris, J.A. 2016. Lionfish: a major marine invasion. Marine Ecology Progress Series, 558: 161-165.

Kulbicki, M., Beets, J., Chabanet, P., Cure, K., Darling, E., Floeter, S.R., Galzin, R., Green, A., HarmelinVivien, M., Hixon, M.A., Letourneur, Y., Loma, T.L., McClanahan, T., McIlwain, J., MouTham, G., Myers, R., O'Leary, J.K., Plans, S., Vigliola, L. \& Wantiez, L. 2012. Distributions of Indo-Pacific lionfishes Pterois spp. In their native ranges: implications for the Atlantic invasion. Marine Ecology Progress Series, 446: 189-205.

de León, R., Vane, K., Bertuol, P., Chamberland, V.C., Simal, F., Imms, E. \& Vermeij, M.J.A. 2013. Effectiveness of lionfish removal efforts in the southern Caribbean. Endanger Species Research, 22: 175-182.

Lesser, M.P. \& Slattery, M. 2011. Phase shift to algal dominated mesophotic communities at depths associated with lionfish (Pterois volitans) on a coral invasion Bahamian reef. Biological Invasions, 13(8): 1855-1868.

Malpica-Cruz, L., Keys, L.C.T. \& Côté, I.M. 2016. Managing marine invasive species through public participation: lionfish derbies as a case study. Marine Policy, 74: 158-164.

McTee, S.A. \& Grubich, J.R. 2014. Native densities, distribution, and diurnal activity of Red Sea lionfishes (Scorpaenidae). Marine Ecology Progress Series, 508: 223-232.

Sabido-Itzá, M.M., Aguilar-Perera, A. \& Medina-Quej, A. 2016a. Length-weight and length-length relations, and relative condition factor of red lionfish, Pterois volitans (Actinopterygii: Scorpaeniformes: Scorpaenidae), from two natural protected areas in the Mexican Caribbean. Acta Ichthyologica et Piscatoria, 46(4): 279-285.

Sabido-Itzá, M.M., Medina-Quej, A., de Jesús-Navarrete, A., Gómez-Poot, J.M. \& García-Rivas, M.C. 2016 b. $\mathrm{La}$ estructura de tallas como evidencia del establecimiento de Pterois volitans (Scorpaeniformes: 
Scorpaenidae) en el sur del Caribe mexicano. Revista de Biología Tropical, 64(1): 369-378.

Tilley, A., Carter, E., Wassermann, S. \& López-Angarita, J. 2016. Enhancing management of invasive lionfish using distance sampling and detection probability. Aquatic Conservation, 26(2): 279-288.

Received: 8 September 2017; Accepted: 3 October 2018
Villegas-Sánchez, C.A., Lara-Arenas, J.H., Castro-Pérez, J.M. \& Arias-González, J.E. 2015. Patrones de reclutamiento de 4 especies ícticas en hábitats de parche y cordillera del arrecife Banco Chinchorro (Caribe mexicano). Revista Mexicana de Biodiversidad, 86(2): 396-405. 